VOLUME $10 \quad$ No. 2, 22 Agustus- 2020 Halaman 234-250

\title{
LISTRIK DAN PERUBAHAN SOSIAL PADA MASYARAKAT DESA TERPENCIL STUDI KASUS PADA MASYARAKAT DUSUN PUNIK, KECAMATAN BATU LANTEH, KABUPATEN SUMBAWA
}

\section{ELECTRICITY AND SOCIAL CHANGE IN REMOTE VILLAGE COMMUNITIES A CASE STUDY ON THE PUNIK VILLAGE COMMUNITY BATU LANTEH DISTRICT, SUMBAWA REGENCY}

*Taufiq Ramdani

Program Studi Sosiologi Universitas Mataram

Submitted: 22-10-2019; Revised: 25-07-2020; Accepted:25-07-2020

\begin{abstract}
Electricity has been a vital force of soclial change. Access to electricity is an inevitable drive to multidmentional transfromation of society. The purpose of this research is to describe the forms of social change that occurs in Punik remote rural communities as a result of the presence of diesel generating electrical power (generator) in 2005. Based on a qualitative conducte in Punik Village of Batu Lanteh Subdistrict of Sumbawa regency, this research found the following conclusions: (a) shifts in the layers of social status, which is based on the extent of the diversity of manifestations and clumps of technology that can have, how expensive, how far the complexity or level of sophistication, how people are able to do and have it , (b) changes in the distribution of roles in the family and society, where the role of the family and society to adapt following the relative availability of resources beyond the normative criteria, namely gender and age, (c) shifts in basis and the orientation of interaction and cooperation of the elements of intimacy that strengthen kinship and altruism shifted into affective neutrality, individual and economy-oriented interests, (d) shift in the tradition, includig a variety of oral tradition that includes the inauguration of the relationship between individuals that is reduced by functions clump technology innovation; other collective traditions are relatively easier stimulus delivered through the entertainment medi; (e) The change of culture, a culture which previously relied on a livelihood, the human role and traditional equipment based technologies manifestation are displaced by electrical function, (f) the changes social events to adapt with electrical availability.
\end{abstract}

Keywords: Diffusion; Electricity; Generator; Innovations; Remote Indigenous Communities; Social Change.

${ }^{*}$ Corresponding author: taufiq.ramdani@unram.ac.id

Copyright@ 2020 THE AUTHOR (S). This article is distributed under a Creative Commons Attribution-Share Alike 4.0 International license. Jurnal Kawistara is published by the Graduate School of Universitas Gadjah Mada. 


\begin{abstract}
ABSTRAK
Listrik telah menjadi sumber perubahan sosial yang penting. Kedatangan listrik pada masayarakat terpencial bisa dipastikan mendorong terjadinya perubahan sosial dalam berbagai bidang. Tujuan penelitian ini adalah untuk menggambarakan dimensi-dimensi perubahan sosial yang terjadi sejak masuknya akses terhadap Pembangkit Listrik Tenaga Disel (PLTD) pada tahun 2005 di masyarakat dusun Punik, desa Batu Dulang, Kecamatan Batu Lanteh Kabupaten Sumbawa. Penelitian menggunakan pendekatan kualitatif dengan desain studi kasus dusun Punik kecamatan Batu Lanteh Kabupaten Sumbawa. Dengan menggunakan metode analisis interaktif Miles dan Habermas, penelitian ini menemukan sejumlah perubahan sosial sebagai berikut (a) Pergeseran basis pelapisan atau ukuran status sosial yang bertumpu pada sejauhmana keberagaman manifestasi dan rumpun teknologi yang mampu dimiliki, seberapa mahal harganya, sejauhmana kompleksitas atau tingkat kecanggihannya, seberapa orang yang mampu melakukan dan memilikinya. (b) Perubahan distribusi peran dalam keluarga dan masyarakat, di mana peran dalam keluarga dan masyarakat beradapatasi mengikuti ketersediaan sumber daya yang relatif melampaui kriteria normatif yaitu jenis kelamin dan usia. (c) Pergeseran basis dan orientasi interaksi dan kerjasama, dari unsur afektivitas dan orientasi keintiman, menguatkan hubungan kekerabatan serta altruisme bergeser menjadi affective neutrality, individual dan berorientasi ekonomi. (d) Pergeseran tradisi, berbagai tradisi lisan yang memuat pengukuhan hubungan antara individu direduksi oleh fungsifungsi rumpun teknologi inovasi. Sedangkan tradisi-tradisi kolektif lainnya relatif lebih mudah terselenggara melalui stimulus media hiburan. (e) Perubahan budaya, budaya yang sebelumnya bertumpu pada sistem mata pencaharian, pada peran manusia dan peralatan tradisional tergeser oleh manifestasi teknologi berbasis fungsi listrik. f) Momentum-momentum sosial beradaptasi berdasarkan manifestasi kelistrikan.
\end{abstract}

Kata Kunci: Adopsi; Difusi; Genset; Kelistrikan; Komunitas Desa Terpencil; Perubahan Sosial.

\section{PENGANTAR}

Listrik dengan segenap utilitasnya merupakan tuntutan dan keharusan pada hampir semua varian kebutuhan hidup masyarakat, termasuk pada masyarakat pedesaan yang terpencil sekalipun seperti masyarakat dusun Punik Kecamatan Batu Lanteh Kabupaten Sumbawa. Masyarakat mana yang tidak mengenal televisi yang tidak mendambakan telepon genggam, kulkas, lampu penerang, dan lain-lain yang dengannya masyarakat dapat mengenal dan berinteraksi dengan dunia dan budaya luar, dapat beraktivitas lebih efektif, produktif serta efesien. Perubahan-perubahan sosial sebagai dampak berinteraksi dengan budaya luar melalui media informasi dan telekomunikasi merupakan salah satu faktor yang selama ini mendominasi perubahan sosial dalam suatu masyarakat, baik masyarakat kota terlebih masyarakat desa yang yang terpencil seperti dusun Punik. Menelaah bahwa listrik tidak saja berperan sebagai sarana ekonomi, tetapi sebagai sarana sosial juga, tidak saja sebagai generator energi gerak bagi teknologi (peradaban) juga generator budaya, maka patut diperhitungkan bahwa perubahan yang disebabkan oleh keberadaan listrik tidak saja berdampak pada ekonomi dan peradaban, berdampak pada aspek sosial dan budaya. Terlebih bagi masyarakat Desa terpencil di puncak gugusan gunung Kabupaten Sumbawa yaitu Dusun Punik yang sebelumnya tidak memiliki tradisi dan budaya yang secara intensif berafiliasi dengan penggunaan listrik. Di hadapan masyarakat yang masih sangat terpencil dan jauh dari jangkauan infrastruktur perkotaan, kehadiran listrik bisa jadi dianggap sebagai sesuatu yang sangat baru bagi mereka, bahkan dapat dianggap sebagai suatu inovasi yang kemudian berproses dalam adopsi dan difusinya untuk kemudian membentuk budaya baru. Sebagai sesuatu yang dianggap baru layaknya sifat inovasi, listrik menempuh kelazimannnya untuk membawa perubahan sosial karena inovasi tidak selalu berhasil dalam perjuangannya untuk menjadi budaya dan pranata baru, bergantung pada sifatsifatnya, keuntungan relatif yang sesuai dengan kebutuhan sasaran, kesesuaian dengan norma dan budaya setempat, relefansi media komunikasinya, kehandalan agent inovasinya, serta dukungan pemuka dan tokoh masyarakat setempat. Tidak jarang bahwa suatu inovasi gagal berdifusi dan kemudian menjadi 
cerita kegagalan semata. Keberhasilan dan kegagalan proses difusi inovasi yang pada akhirnya menghantar pada perubahan sosial tidak terlepas dari beberapa faktor selain dari faktor eksternal inovasi yang mendukungnya. Menurut Rogers (1983), beberapa faktor tersebut yaitu terkait dengan sifat-sifat inovasi antara lain: (1) relative advantage (keuntungan relatif), (2) compatibility (kesesuaian), (3) complexity (kerumitan), (4) trialability (kemungkinan di coba), dan (5) observability (keteramatan hasilnya).

Adapun faktor-faktor ekternal inovasi yang terdapat pada diri masyarakat sebagai calon penggguna, yaitu (1) tingkat pendidikan, (2) kemampuan ekonomi, (3) tradisi dan norma, (4) usia, (5) interaksi dengan budaya luar (kosmopolit), (6) agen inovasi, (7) pemuka dan tokoh masyarakat, (8) saluran komunikasi inovasi, dan mungkin juga di luar dugaan masih ada faktor-faktor lainnya yang hanya dapat diketahui setelah penelitian dilakukan. Berbagai keterbatasan teknis PLTD yang kemudian berkorelasi dengan tingkat implementasi pemanfaatan listrik oleh masyarakat sedikit tidak berdampak terhadap pasang-surutnya laju perubahan sosial yang dihasilkannya, tetapi demikian tetap menghasilkan perubahan yang serupa dengan perubahan yang ditimbulkan oleh keberadaan listrik pada umumnya. Berbagai keterbatasan yang dimaksud yang melekat pada PLTD yaitu mencakup dependabilitas terhadap temperatur cahaya matahari, artinya listrik hampir tidak tersedia di musim hujan, kemudian daya listrik yang kecil dan terbatas sehingga teknologi yang tersupport sangat minim seperti radio beberapa jam, televisi beberapa saat, serta keterbatasan sistem pendapatan masyarakat yang bersifat periodik-anually (tahunan) yang berdampak pada tingkat perawatan teknologi PLTD saat mengalami kerusakan dan membutuhkan perbaikan. Mengacu kepada kondisi tersebut, maka apabila dipetakan secara periodik, akan terlihat jelas bahwa pada satu titik periode tertentu PLTD dan dampaknya perubahan sosialnya mengalami perkembangan yang konstan, lalu melambat bahkan cenderung stagnan, tetapi pada suatu waktu berjalan kembali. Dusun Punik dihuni oleh sekelompok kecil masyarakat asli Sumbawa yang mendiami satu desa yang sangat terpencil yang terletak di atas gugusan pegunungan kecamatan Batu Lanteh Kabupaten Sumbawa. Tradisi lisan menuturkan bahwa mereka merupakan bagian dari nenek moyang masyarakat Sumbawa yang tersebar sampai ke Desa Tepal dan Batu Rotok karena menghindari kesewenangan penjajah lalu mengasingkan diri dan menetap di tempat tersebut dengan cara membuka lahan baru. Mereka adalah masyarakat yang kini hidup dari berkebun kopi. Kurang lebih sebelum 30 tahun yang lalu, mereka adalah masyarakat yang menggantungkan hidupnya dari hasil hutan serta pertanian tadah hujan.

Di era sebelum tahun 1990-an, populasi masyarakat Punik mengalami pasang surut disebabkan mata pencaharian yang tidak menentu yang diperparah dengan sulitnya akses berinteraksi dengan dunia luar sebagai upaya untuk mencari solusi alternatif. Ketiadaan sistem irigasi, tekstur serta komposisi tanah menyebabkan pertanian tadah hujan yang tidak dapat diandalkan kehandalannya untuk mencukupi kebutuhan hidup mendorong migrasi ke luar Desa, dan tindakan tersebut merupakan pilihan yang layak di kala itu. Keterpencilannya yang sangat jauh dari berbagai akses dan infrastruktur juga turut menghambat laju pendatang, walaupun sekedar untuk kunjungan atau berdagang. Dimulai dari awal tahun 1990an, beberapa keluarga yang tergolong pioner migrasi ke tempat tersebut, mencoba alternatif penghidupan yang lain, yaitu dengan membuka lahan untuk perkebunan kopi. Secara mengejutkan, hasilnya sangat bagus. Namun tindakan penjualan di kala itu masih dilakukan melalui "barter" dengan kebutuhan pokok, yaitu beras, minyak goreng, sedikit minyak tanah, garam, dan gula. Siring waktu mulailah pemasaran menjangkau kota Sumbawa besar hingga terbentuklah jaringan dagang yang jelas dan permanen seperti sekarang ini. Seiring waktu, berbagai perkembangan merambah masyarakat Dusun Punik, salah satunya yaitu kehadiran PLTD (Mesin Genset). Genset sebagai sumber pembangkit listrik tenaga 
diesel tidaklah semaksimal pembangkit listrik yang dikenal umumnya di perkotaan karena Genset sebagai PLTD di Dusun Punik bukanlah infrastruktur yang dibangun atau dimiliki oleh PT.PLN Persero, melainkan seperangkat pembangkit listrik dari diesel yang dibeli dan dikelola secara bersama-sama (patungan) oleh masyarakat setempat, lalu aliran listrik yang dihasilkan dialirkan ke rumah-rumah anggota atau yang besedia membayar sesuai ketentuan yang mereka tetapkan sendiri. Sejak itulah lambat tapi pasti perubahan kehidupan dan sosial budaya masyarakat Punik mulai berlangsung lebih cepat untuk layak disebut sebagai tahapan evolutif.

Fakta dan fenomena yang sudah diuraikan di atas, maka penulis dalam hal ini tertarik untuk meneliti tentang Bagaimana perubahan sosial yang terjadi pada masyarakat terpencil Dusun Punik Kabupaten Sumbawa sebagai dampak pasang surutnya keberadaan listrik PLTD? Tulisan ini menggunakan paradigma kualitatif dengan desain penelitian studi kasus, yang mana pengkajiannya dilakukan secara rinci terhadap latar, orang-orang, subjek serta tempat dan peristiwa yang menjadi sasaran penelitian. Sebagai penelitian dengan desain studi kasus, maka penelitian ini akan memusatkan penelitian dan pengkajian pada proses serta dampak yang diakibatkan oleh keberadaan PLTD (Genset) terhadap perubahan-perubahan kultur, struktur, dan interaksi masyarakat Dusun Punik dengan kriteria sebagai berikut: (1) sasaran penelitiannya berupa manusia yaitu keluarga Dusun Punik, sedangkan peristiwa yaitu yang terkait dengan proses pemanfaatan PLTD (Genset) serta difusina dengan latar bekalang budaya masyarakat setempat (2) sasaransasaran tersebut di atas kemudian ditelaah secara mendalam sebagai suatu totalitas sesuai dengan latar atau konteksnya guna mernahami berbagai kaitan yang ada di antara variabelvariabelnya. Adapun lokasi penelitian ini adalah Dusun Punik kecamatan Batu Lanteh Kabupaten Sumbawa. Masyarakat Dusun Punik menempati kawasan tinggi dari hutan perbukitan yang membentang di pedalaman kabupaten Sumbawa. Sulitnya perjalanan menuju Dusun Punik dapat menjadi penjelasan tersendiri atas predikat keterpencilan yang mereka sandang. Masyarakat Dusun Punik merupakan icon tersendiri tentang keterpencilan dan tradisionlitas di masyarakat Sumbawa. Mereka hidup bertani kopi dan mengonsumsi makanan sehari-hari dengan mengambilnya langsung dari alam. Akan tetapi, telah hadirnya listrik walaupun dengan skala daya dan durasi pemanfaatan yang sangat terbatas, tetaplah nampak perubahanperubahan yang dapat dikatakan signifikan yang mencakup aspek sosial, ekonomi, dan komunikasi. Kegiatan penelitian efektif dilakukan selama satu tahun.

Merujuk pada latar belakang maka penelitian ini difokuskan pada bagaimana "dampak kehadiran listrik PLTD (Mesin Genset) terhadap perubahan sosial yang terjadi pada Masyarakat Dusun Punik Kabupaten Sumbawa. Kegiatan penelitian dan pengkajian akan dilakukan secara kontinu, dengan asumsi bahwa proses terjadinya perubahan sosial didahului oleh kemunculan PLTD (Genset) dan bentuk-bentuk pemanfaatannya, untuk kemudian sampai kepada bentuk perubahan sosial yang dihasilkannya. Pemilihan informan di dalam penelitian ini tidak hanya meliputi keputusan tentang orang-orang yang akan diamati atau diwawancarai. Akan tetapi, mengenai latar belakang, peristiwa-peristiwa dan proses-proses sosial yang meliputi persepsi terkait nilai manfaat PLTD (Genset), lalu manifestasi persepsi tersebut di dalam proses pemanfaatan dan implementasi listrik di dalam kehidupan masyarakat, kemudian perubahan sosial yang diakibatkannya. Oleh karena itu, kerangka konseptual penelitian ini terskema ke dalam hal-hal tersebut di atas, maka batas-batas penentuan dan pemilihan informanpun mengikuti aspek tersebut serta distribusi-distribusinya. Kegunaan informan bagi peneliti ini adalah sebagai sumber mendapatkan informasi atau data tentang perubahan sosial yang berlangsung di tengah masyarakat Dusun Punik sebagai dampak keberadaan listrik PLTD (Genset). Kegunaan informan dalam penelitian ini tidak saja untuk tujuan di atas, tetapi juga untuk tujuan 
sebagaimana predikatnya di dalam penelitian kualitatif yaitu sebagai internal sampling yang juga dimanfaatkan untuk berbicara, bertukar pikiran, atau membandingkan suatu kejadian yang ditemukan dari subyek lainnya.

Dengan maksud dan tujuan di atas, maka informan dalam tulisan ini ada dua informan: (a) Informan kunci (menggunakan metode purposive sampling), yaitu Kepala Dusun Punik, Tokoh Agama (Imam Masjid) Punik, Sesepuh atau Tokoh Adat Dusun Punik, Ketua Kelompok Pengelola PLTD, dan Kepala Sekolah setempat. (b) Informan Pendukung (menggunakan metode Snowball Sampling): Dari informan kunci tersebut di atas peneliti menanyakan orang-orang yang perlu ditemui untuk mendapatkan informasi atau data yang mengacu pada kerangka operasional penelitian. Perlu dijelaskan sekali lagi bahwa unit analisis di dalam penelitian ini adalah keluarga, di mana informan kunci dipilih secara purposive dengan menggunakan criterion based selection yaitu mereka yang mengetahui secara memadai tentang inovasi listrik, tentang pandangan atau persepsi yang beredar luas di tengahtengah masyarakat terkait nilai keberadaan inovasi listrik, tentang proses adopsi-difusi, dan tentang perubahan sosial yang terjadi. Adapun beberapa informan pendukung di atas diperoleh melalui metode Snowball Sampling, yaitu informan yang ditentukan berdasarkan informasi dan arahan dari informan kunci yang disesuaikan dengan kerangka penelitian.

Berdasarkan pada jenis dan sumber data yang diperlukan, teknik pengumpulan data yang digunakan dalam penelitian, meliputi: pertama, Observasi partisipatif, dilaksanakan peneliti dengan cara menginap dari satu rumah keluarga Dusun Punik yang satu ke rumah lainnya secara berpindah-pindah, sembari peneliti mengamati dan mengikuti rangkaian rutinitas kehidupan masyarakat Dusun Punik Kabupaten Sumbawa yang difokuskan pada aktualisasi persepsi, aktualisasi keinovasian serta perubahan-perubahan sosial yang terjadi meliputi: kultur dan tradisi, struktur sosial, dan sistem interaksi. Teknik observasi partisipasi dimaksudkan selain untuk mendapatkan datadata tersebut di atas juga tidak kalah pentingnya adalah untuk mengamati perubahan perilaku Masyarakat Dusun Punik sebagai salah satu fenomena yang menandai perubahan sosial di tengah-tengah mereka sebagai dampak kehadiran listrik.

Kedua, Wawancara mendalam (Indepth Interview), teknik ini dilakukan dengan wawancara mendalam yang dilaksanakan secara langsung, yaitu keluarga-keluarga sebagai anggota masyarakat Dusun Punik didatangi dan diwawancarai secara wajar, tetapi mendalam, khususnya yang terkait dengan persepsi serta motif-motif atau latar di balik tindakan mereka di dalam pemanfaatan energi listrik serta perubahan kehidupan yang mereka jalani. Diupayakan bahwa latar penelitian ini alamiah dan wajar agar diperoleh data yang benar-benar apa adanya atau alamiah. Untuk menghindari kesan formal yang dikuatirkan akan menggiring informan pada penyampaian informasi yang bias, maka wawancara yang menyerupai percapakapan biasa ini dilakukan seusai sarapan pagi, seusai sarapan malam serta di sela-sela menonton televisi atau mendengarkan radio. Beberapa wawancara dilakukan secara intensif dengan kepala Desa, dengan tokoh adat dan pemuka masyarakat, tokoh agama, kepala sekolah, para pengurus atau pengelola Usaha Listrik Tenaga Diesel (PLTD), dan beberapa informan kunci lainnya. Oleh karena itu, Masyarakat Dusun Punik mayoritas adalah petani kopi dan mereka seharian akan berada di kebun kopi maka wawancara juga dilakukan secara berkala di ladang kopi mereka.

Ketiga, Dokumenter bahwa teknik ini dilaksanakan dengan cara pengumpulan data yang bersumber pada dokumen-dokumen baik yang ada pada situs penelitian (lokasi penelitian) maupun di instansi atau lembagalembaga yang berkompeten dan fokus terhadap Masyarakat Dusun Punik, seperti kantor Desa, pusat pengelolaan unit PLTD, dan segenap SKPD di Pemerintah Daerah Kabupaten Sumbawa. Analisis data yang dipergunakan dalam penelitian ini adalah analisis kualitatif yaitu analisis yang dilakukan dengan menggunakan model interaktif. Pada model ini terdapat tiga komponen analisis yaitu reduksi, sajian data, dan penarikan kesimpulan 
(Miles dan Huberman, 1992). Selanjutnya analisis dilakukan dengan memadukan (secara interaktif) ketiga komponen tersebut. Keabsahan data hasil penelitian ini diupayakan melalui penggunaan beberapa teknik yang dari berbagai sisi menunjang keabsahan data penelitian ini yang mencakup kredibilitas, dependabilitas, transferabilitas, dan komfirmabilitas.

\section{PEMBAHASAN \\ Implementasi Listrik PLTD dalam Kehidupan Keseharian Masyarakat Punik.}

Pemanfaatan energi listrik dari mesin genset sejatinya sudah dilakukan cukup lama oleh masyarakat Punik, baik digunakan untuk keperluan individual maupun kelembagaan (Masjid, acara desa, dan lain-lain), tetapi pemanfaatannya temporal dan pada momentum-momentum tertentu atau pada waktu-waktu tertentu saja. Setelah berjalan cukup lama masyarakat kemudian terdorong untuk membiayai dan mengelolanya secara bersama-sama agar lebih meringankan dan efesien. Setelah memasuki fase pengelolaan berkelompok ini maka tiga bulan pertama adalah masa penguatan kelembagaan serta sosialisasi yang mana instalasi baru saja dilakukan di sentra-sentra kegiatan masyarakat seperti masjid, kantor Desa, sekolah, dan rumah-rumah tertentu. Tiga bulan kedua instalasi sudah mempunyai kerangka regulasi penggunaan dan pembayaran sehingga terminologi yang digunakan sudah merambah ke ranah jual-beli. Konsumen pertama adalah para keluarga ekonomi kuat dan terpandang, mereka terdiri dari Masyarakat Dusun Punik yang memiliki luas lahan di atas 10 Hektar, pemimpin formal yaitu Kepala Desa dan Kepala Sekolah, dan punggawa perdagangan yaitu pengepul kopi dan rempah-rempah. Memasuki triwulan ketiga yang kebetulan bersamaan dengan even-even berikut ini: (1) Masa panen kopi pertama sejak PLTD (Mesin Genset) dikenal dan dimanfaatkan secara massif di Dusun Punik. (2) Parabola sebagai pintu pertama pemanfaatan PLTD (Mesin Genset) bagi teknologi serumpun sudah tersebar di beberapa sudut Desa. (3) Pararelisasi sinyal siaran dari parabola sudah mulai dikenal dan dilakukan. (4) Masyarakat telah menemukan berbagai kerangka pemanfaatan yang diinginkan terhadap keberadaan inovasi listrik.

Secara faktual, gerak berinovasi tumbuh dan berkembang cepat setiap musim panen kopi. Segera setelah panen kopi, masyarakat seakan berlomba-lomba menunjukkan kemampuan berinovasi listrik, yang mana sebelumnya berlomba-lomba di dalam kemampuan menimbun keragaman kebutuhan pokok. Begitu menginjak bulan kedua sampai bulan keempat pascapanen kopi, gerak berinovasi kembali melambat, dan puncaknya akan mengalami titik fakum di bulan kesebelas dan seterusnya, yaitu di waktu memasuki musim hujan. Pada masa ini, berbagai budaya dan tradisi baru sebagai implementasi PLTD juga terhenti.

Sebagaimana konsepsi teori difusi inovasi Rogers bahwa suatu inovasi akan sangat dipengaruhi oleh faktor kompatibilitasnya dalam proses dan perjalanannya untuk terus terdifusi ataukah harus terhenti. Kompatibilitas suatu invensi dan inovasi tidak saja diukur kesesuaiannya dengan nilai dan norma setempat, melainkan dengan karakteristik-karakteristik topografi dan tantangan-tantangan yang ditimbulkannya. Beberapa peneliti sebelumnya menunjukkan bahwa kompatibilitas suatu inovasi harus ditunjang oleh karakteristik topografi dan konsekuensi yang ditimbulkannya. Hasil penelitian ini menunjukkan bahwa betapa musim hujan bukan saja faktor yang menguji diskompatibilitas inovasi PLTD, tetapi kemampuan pengurus PLTD di dalam mengantisipasi dan menyiasati kelangkaan bahan bakar PLTD di setiap akan memasuki musim hujan. Menimbun stok solar dalam jumlah yang mencukupi sampai musim hujan berlalu merupakan upaya yang berluang kali gagal dan kegagalan tersebut terkait dengan ketidak-mampuan segenap masyarakat untuk mengalokasikan dana yang cukup untuk hal itu. Pada periode ini, tidak saja tidak ada adopter baru melainkan juga tidak ada pemanfaatan 
baru, bahkan cenderung meninggalkan pola pemanfaatan yang sudah berjalan, artinya lebih lanjut bahwa laju perubahan sosial yang dikendalikan oleh implementasi PLTD juga terhenti. Kefakuman ini disebabkan alasanalasan berikut ini: Pertama, Kendala musiman yaitu terbatasnya kesempatan pengelola untuk turun ke kota guna membeli bahan bakar PLTD disebabkan perjalanan yang berbahaya, kemudian berdampak pada pengurangan suplai listrik ke rumah-rumah penduduk dan pembatasan waktu penggunaannya. Kedua, Meningkatnya penggunaan listrik PLTD secara sporadis yang disebabkan oleh tidak berfungsinya Pembangkit Listrik Tenaga Surya. Untuk diketahui bahwa bagi 30 keluarga masyarakat Dusun Punik yang masih memiliki PLTS, fungsi penerangan di luar musim hujan masih ditanggulangi dengan PLTS yang zero cost. Akan tetapi, begitu memasuki musim hujan di mana kualitas sinar matahari menurun dan tidak menentu menyebabkan PLTS tidak berfungsi. Ketiga, Salah satu peraturan yang dimaksud adalah pelarangan dan pembatasan penggunaan televisi, video-player, radiotape, dan pemutusan semua aliran pada waktu-waktu tertentu untuk mengatasi kendala keterbatan stok bahan bakar untuk operasionalisasi PLTD.

Dampak praktis dari kondisi tersebut di atas, secara langsung menghentikan tahapan keinovasian sampai musim hujan berlalu yang pastinya juga berpengaruh terhadap laju perubahan sosial. Pada masa-masa ini terjadi disformasi tradisi dan budaya. Beberapa tradisi yang ditimbulkan oleh inovasi PLTD mulai kehilangan substansi dan kerangka materialnya, berkumpul sampai larut malam tanpa satu bahasan dan tujuan yang terencana.

Masa-masa kefakuman sebagaimana dijelaskan di atas, mengembalikan beberapa tradisi lama yang sebelumnya sempat tersingkirkan oleh fungsi keberadaan inovasi listrik. Misalnya, seusai sholat isya' mayoritas masyarakat sudah tampak tidak melakukan aktivitas apapun dan memilih tidur. Tidak saja pada kecenderungan beraktivitas, tematema atau isu komunikasi dan interaksi juga ikut berubah, tidak lagi seputar atribut inovasi, hiburan, dan budaya-budaya yang dihasilkannya, sehingga tradisi-tradisi lama seperti tradisi "betuter" (saling bercerita saat senggang) yang memang fungsional dengan periode musim hujan kala itu dan sempat tergeser oleh manifestasi tradisi-tradisi inovasi kembali menjadi pilihan. Akan tetapi, beberapa keluarga tetap membuat pilihan berbeda di masa fakum tersebut. Pilihan yang dimaksud adalah alternatif mendapatkan fungsi atribut inovasi seperti menonton televisi dan mendengarkan radio-tape walaupun dalam waktu dan tempat yang terbatas. Sebagaimana telah dijelaskan sebelumnya bahwa pada musim hujan seperangkat aturan yang disepakati antara warga dan pengelola PLTD diputuskan melalui musyawarah bersama. Seperangkat aturan tersebut terkait pembatasan penggunaan fungsi listrik, pembatasan waktu, pengaturan pemanfaatan secara bergilir, dan pemutusan aliran dalam waktu-waktu tertentu untuk tujuan penghematan bahan bakar PLTD.

Norma yang mengatur tentang pemanfaatan inovasi listrik semasa musim hujan tersebut di atas telah berlaku setiap musim hujan pada setiap tahunnya sejak inovasi listrik PLTD terimplementasi dalam kehidupan Masyarakat Dusun Punik. Dengan demikian, dialektika antara inovasi dan faktor alam telah melahirkan norma dan tradisi tertentu pada Masyarakat Dusun Punik. Sebagaimana teori fungsional struktural bahwa dalam suatu sistem sosial masyarakat manapun selalu terjadi gerak perubahan akibat kemunculan struktur-struktur baru yang mana perubahan tersebut bertujuan untuk menjaga keseimbangan dan kesinambungan sistem tersebut.

Masih di penghujung tahun yang sama, yaitu di akhir tahun 2005 kegagalan panen kopi turut memperparah dan menghadang laju pertumbuhan dan perkembangan keinovasian dan implementasinya. Pada tahun ini terjadi kegagalan hebat yang mengakibatkan kerugian yang cukup banyak bagi petani kopi. Di satu sisi beberapa petani memiliki hutang di sejumlah pengepul untuk keperluan tanaman kopi mereka, ada pula yang untuk kebutuhan pokok, dan untuk kebutuhan implementasi PLTD. 
Kondisi ini berdampak serius pada surutnya laju keinovasian dan implementasinya sebagai salah satu wujud surutnya laju perubahan sosial.

Memasuki tahun kedua sejak inovasi listrik PLTD pertama kali dikenal Masyarakat Dusun Punik, keadaan dan kefakuman yang disebabkan oleh faktor musim hujan di atas mulai berlalu, tetapi dengan catatan bahwa faktor musim hujan akan kembali lagi pada tahun mendatang. Di awal tahun kedua ini yang bersamaan dengan masa panen kopi, geliat keinovasian, dan aktualisasinya di dalam perubahan sosial mulai merambah ke struktur-struktur lain dari sistem sosialbudaya masyarakat Punik, bahkan cenderung lebih inovatif. Dampak lebih jauh lagi bahwa seiring dengan meningkatnya kebutuhan implementasi serta aktualisasi masyarakat di dalam berinovasi, yaitu meningkatnya permintaan terhadap teknologi-teknologi berenergilistrik, berdampak pada kemunculnya struktur ekonomi baru. Struktur ekonomi baru yang dimaksud adalah kemunculan pola perdagangan yang sebelumnya hanya dikenal di masyarakat urban, yaitu sistem kredit, sistem makelar dengan segenap kompensasi jasanya, juru tagih, sampai pada penyitaan, dan mediasinya.

Tentu saja, kompleksitas perdagangan sistem kredit beserta serangkaian pranatapranata penunjangnya di atas tidak saja berpengaruh pada aspek struktur masyarakat Punik, tetapi juga mendatangkan pengaruh yang beruntun pada perubahan aspek-aspek mentalitas, hubungan kekerabatan, dan pola interaksi mereka. Adapun yang paling serius perubahannya adalah pada kemunculan motif kompensasi atau imbal jasa. Bagi beberapa orang terlibat di dalam kegiatan di atas, khususnya yang melakoni peran makelar, perilaku sosial yang ditinjukkannya di dalam berinteraksi mulai menampakkan motif berperilaku masyarakat patembayan, yang penuh dengan motif imbal jasa ekonomi. Patut dikuatirkan bahwa mentalitas serta pola interaksi yang begitu bercorak urban tersebut akan menjalar ke segenap masyarakat Punik lainnya.

\section{Modifikasi dan Perubahan Kultur Masyarakat Dusun Punik}

Pemanfaatan PLTD telah merambah ke berbagai aspek kehidupan Masyarakat Dusun Punik. Fungsi dan implementasi beberapa kultur lama digantikan oleh kultur teknologi berlistrik dan manifestasinya. Mungkin saja kemasannya masih sama, tetapi muatan dan substansinya sudah berbeda, individuindividu masih sering berkumpul membentuk satu kelompok, dan orientasinya sudah bukan kepada orang-orang dan hubungan, melainkan kepada benda-benda.

Teori konvergensi yang bentuk klasiknya berkaitan erat dengan determinisme teknologi (tokoh-tokohnya adalah Huntington dan Rostow) mengatakan bahwa teknologi dominan memaksakan (menimbulkan) bentuk baru organisasi sosial, kultur, perilaku seharihari dan keyakinan, dan sikap (Sztompka, 1993). Manifestasi beberapa teknologi berbasis listrik PLTD tidak selalu menimbulkan kultur yang benar-benar baru kemasan maupun muatannya. Beberapa kultur baru masih sama kemasannya dengan yang lama, hanya saja substansi dan muatannya sudah berbeda. Ada pula yang kemasannya berbeda, tetapi substansi muatannya masih serupa. Sebut saja kasus-kasus yang semisal yaitu berkumpulnya orang-orang pada suatu tempat yang sama, tetapi tujuan yang sudah berubah. Sepulang dari ladang, masyarakat Punik masih berkumpul di tempat yang sama yaitu di pelataran rumah Kepala Desa atau diujung gang Desa, tetapi mereka tidak lagi mempraktikkan kebiasaan sebelumnya yaitu betuter (saling bercerita), melainkan untuk mendengarkan radio. Kemasannya masih berkumpul dan mendengarkan, tetapi substansi dan muatannya tidak lagi antarorang dan perorang, melainkan antara benda dan orang-orang.

Sebelum era keinovasian, terdapat satu kebiasaan masyarakat Punik untuk mengisi ruang waktu yang kosong dengan peningakatan kualitas hubungan sosial. Disebut saja kebiasaan itu sebagai tradisi, yaitu betemue. Sebelum fase keinovasian, tradisi ini merupakan tradisi bertamu yang dilakukan 
warga Punik tanpa suatu kepentingan apapun, selain hanya untuk mempertahankan hubungan sosial atau menjaga tali silaturrahmi. Muatan kebiasaan yang semula sosial, guyub, dan mekanis ini tiba-tiba saja berubah menjadi bermuatan hiburan semata. Muatan yang berubah ini terukur dari kecenderungan yang terpolarisasi dan tersegmentasi sasarannya yaitu hanya rumah-rumah yang memiliki teknologi hiburan saja.

Penelitian ini menemukan fakta berikutnya bahwa kalangan wanita yaitu ibu-ibu rumah tangga merupakan segmen yang melakukan modifikasi terhadap kemasan-kemasan tradisi lama, tetapi masih mampu mempertahankan muatannya. Mereka memodifikasi kerjasama di dalam tradisi betulong dan betuja nisong. Keduaduanya merupakan tradisi kebersamaan, di mana di dalam tradisi baru peran tersebut diwakilkan kepada benda-benda keinovasian (rice cooker, mixer, blender), tetapi kehadiran mereka dan rempah-rempah yang dibawanya manifestasi kolektivitas atau kebersamaan.

Telepas dari berbagai asumsi perubahan di atas, patut diakui bahwa berbagai bentuk perubahan tradisi yang terjadi pada masyarakat Punik, baik yang hanya dalam bentuk modifikasi ataupun sampai pada penyingkiran, baik yang hanya dalam kemasan ataupun yang sampai pada substansi dan muatamuatannya, ketika dikembalikan pada motivasi berinovasi maka sama-sama berdampak pada keberlangsungan morphologis-normatif, di mana orang-orang berusaha menyingkirkan tradisi lama karena keabsahannya dianggap tidak relefan lagi dengan konteks kekinian mereka.

Efek peralihan tradisi tersebut di atas, yang juga dapat dimaknai sebagai modifikasi dan penyingkirkan tradisi lama juga berarti peralihan orientasi budaya. Secara nyata peristiwa di atas membawa pelakunya ke dalam kesadaran yang determinan dengan manifestasi teknologi tersebut (teralienasi) bahwa secara terukur si pelaku memandang norma dan tradisi yang terkait dengan manifestasi teknologi tersebut (PLTD) sebagai model, modern, dan relefan. Sedangkan dirinya dan tradisi lamanya adalah kolot, tradisional, dan tidak relevan lagi. Dampak nyata dan teramati dari komplekasitas penyingkiran norma dan tradisi lama tersebut tragisnya hanya menyentuh aspek life style yang artifisial dari kehidupan Masyarakat Dusun Punik. Kalangan muda mereka kini lebih gandrung kepada celana jeans sebagai pilihan berbusana untuk pergi ke undangan, atau bahkan pergi ke Masjid untuk sholat jum'at sekalipun. Inilah yang dimaksud oleh Tonnies sebagai kehilangan identitas diri yang tanpa nama (anonim), di mana orang-orang setempat memperlakukan dirinya selayaknya mereka adalah bagian dari dunia luar yang tanpa batas, bukan bagian dari masyarakat dan tradisi tempatnya berpijak (tradisional).

Tradisi atau budaya berikutnya yang termodifikasi atau dapat dikatakan tersingkir oleh manifestasi PLTD adalah tradisi berengo dan berajak. Semula tradisi ini merupakan tradisi oral di dalam mengundang individuindidu pada suatu acara, tetapi setelah fase PLTD yang memungkinkan bagi implementasi komputer dan percetakannya (printer), maka peran oral tersebut diganti oleh peran literal (undangan). Simbol-simbol status sosial turut menumpangi dan kian menguatkan pengadopsian tradisi baru ini.

Guna memahami aspek etnik dari tradisitradisi yang berubah, selama di tengah-tengah Masyarakat Dusun Punik, peneliti menginap secara berpindah-pindah dari satu rumah ke rumah penduduk lainnya, sehingga data tentang bagaimana dan sejauhmana makna dari pilihan keinovasian serta dampakdampak perubahan sosial yang terjadi di dalam keluarga-keluarga Masyarakat Dusun Punik tersebut dapat tercover dengan baik.

Di awal-awal penelitian, demi relefannya metode pengumpulan data dengan alur penelitian, maka peneliti memilih bermalam di rumah Kepala Dusun Punik. Metode ini dipilih dengan maksud untuk memperoleh data awal tentang sejarah-sejarah masyarakat Punik dan perkembangan inovasi sehingga peneliti dapat memahami dengan baik alur perkembangan inovasi sekarang ini. Kepala Dusun Punik merupakan warga Punik, tetapi dengan pengalaman perjalanan dan usaha yang cukup memadai di kota, memiliki luas 
lahan di atas 20 hektar. Di rumah beliau simbol keinovasian dari fungsi PLTD nampak dari kepemilikannya atas satu buah televisi berwarna yang ditunjang serta dilengkapi oleh berbagai teknologi elektronika lainnya. Pada malam hari sehabis sholat isya' mulai beberapa orang berdatangan dan duduk di ruang tamu beberapa rumah yang memiliki fasilitas televisi, termasuk rumah kepala Desa ini, tampaknya mereka adalah penonton televisi yang sering datang di kala malam untuk "nonton bareng" (nonton bersama). Fenomena "nonton bareng" telah membudaya, berlangsung di hampir semua rumah yang memiliki televisi. Dengan demikian dapat diperkirakan bahwa apabila hampir setiap satu rumah yang memiliki televisi terdapat tiga sampai lima keluarga lain yang menumpang untuk menonton, maka fenomena ini sudah mewarnai seluruh penjuru Punik dan telah membudaya.

Sebelum adanya PLTD, tradisi interaksi antarwarga masyarakat Punik berlangsung tradisional dan memanfaatkan pranata peninggalan nenek moyang mereka secara turun temurun. Sebagai contoh, sebagaimana telah disampaikan di atas bahwa undangan kepada warga untuk menghadiri suatu acara atau hajatan dilakukan melalui tradisi "berengo". Tradisi berengo merupakan kombinasi peran antara manusia dan alat kesenian. Peran manusia, dalam hal ini sebagai cerminan kultur Masyarakat Dusun Punik yang "patriarkhi" sehingga harus diperankan oleh mereka yang berjenis kelamin laki-laki, sedangkan alat kesenian harus menggunakan gong, dan gong merupakan alat yang digunakan hampir di setiap bentuk hiburan tradisional masyarakat Sumbawa. Setelah adanya PLTD yang membuka peluang bagi penggunaan komputer dan percetakannya (printer), fungsi berengo sudah mulai ditinggalkan dan undangan disampaikan melalui kartu layaknya yang dikenal di kota sekarang ini. Uniknya lagi bahwa kartu undangan sebagai media interaksi (mengundang) lambat laun berkembang menjadi media aktualisasi prestice atau stasus sosial pula. Bagi masyarakat pedesaan Punik yang terbatas media dan ruang aktualisasi status sosialnya, maka bahan baku undangan dan motif undangan yang tentu saja berdampak pada besaran biaya memproduksinya, lalu di mana undangan itu dicetak serta nama siapa yang dicantumkan sebagai kalangan yang "turut mengundang" menjadi faktor yang memicu persaingan status sosial tersendiri. Bagi keluarga yang dapat mencantumkan nama-nama orang yang dikenal memiliki status sosial-ekonomi yang tinggi di kartu undangannya sebagai yang "turut mengundang", seperti kepala Desa, lebai (imam utama masjid), camat, terlebih bupati, maka akan mendapatkan prestice dan gengsi tersendiri dalam konteks ini.

Tradisi interaksi (mengundang) lainnya yang turut berubah dan mulai ditinggalkan oleh masyarakat Punik setelah mengadopsi PLTD adalah tradisi "berajak". Berajak merupakan metode mengundang secara lisan yang pemeran dan dandanannya disesuaikan dengan segmen atau jenis kelamin yang diundang. Apabila yang diundang adalah kalangan bapak-bapak atau pria maka pemeran "berajak"-pun harus berjenis kelamin pria dengan menggunakan kopiah berwarna hitam, sedangkan apabila yang diundang adalah kalangan ibu-ibu atau wanita yang biasanya bertujuan untuk mengajak mereka membantu kegiatan memasak pihak yang memiliki acara atau hajatan maka yang memerankannya harus berjenis kelamin wanita pula. Dandangan pemeran berajak dari kalangan wanita ini harus dengan melilitkan sarung bermotif warna merah di kepala. Adapun redaksi kalimat yang mereka ucapakan saat mengundang adalah sebagai berikut:

"Assalamu'alaikum. Kayesuru aku undang sia
leng baeng boat ya nansi Bapak Yasin, gama
sia datang pang acara besunat anak diri, katokal
pang bale diri, pang ano Ahad jira turen jemat."
Nan baesi, silamo, Wasssalamu'alaikum.

Artinya: "Assalamu'alaikum. Saya disuruh mengundang anda oleh yang memiliki hajat (acara) yaitu Bapak yasin, semoga ada berkenan hadir di acara sunatan anak beliau, bertempat di rumah beilau, di hari jum'at seusai sholat jum'at. Demikian saja, silahkan. Wassalamu'alaikum. 
Di balik kemasannya secara lisan dan memilah kalangan yang mendengarkan (yang mana metode tersebut tidak dapat dimanifestasi melalu penggunaan speaker), hal ini sebenarnya terdapat muatan status sosial serta muatan tenggang rasa yang dimaksudkan. Muatan status sosial dimaksud terdapat pada urut-urutan pihak yang didatangi (diundang), sedangkan muatan tenggang rasa terdapat pada pihak-pihak yang diundang dan tidak diundang yang disamarkan melalui "kedatangan" tersebut. Penggunaan speaker sebagai implementasi PLTD paling tidak luput dari dua aspek yang dimaksud, sehingga ada nilai-nilai dan norma setempat sebagai kearifan budaya lokal yang tidak tertampung dan terabaikan oleh manifestasi PLTD di dalam sistem interaksi antarwarga ini.

Sebagai aktualisasi homofili keinovasian, masyarakat Punik cenderung memilah segmen pergaulan dan berinteraksi. Konflik terselubung yang dipicu oleh sentimen perbedaan kepemilikan teknologi serta isu ketidak adilan beban tagihan listrik yang disama ratakan turut memperkuat kebelangsungan homofili, dan telah melatar belakangi pengotakan segmen pergaulan yang mereka pilih. Kalangan ekonomi kuat yang memiliki berbagai fasilitas berteknologi listrik, sehingga dapat memaksimalkan konsumsi PLTD cenderung berperilaku homofili dalam mempertahankan sistem tagihan yang ada serta meningkatkan aktualisasi kelasnya, sementara ekonomi lemah yang sangat minimalis di dalam memanfaatkan fungsi PLTD ber-homofili dalam keprihatinan dan gugatan mereka terhadap sistem tersebut. Tarde, satu abad yang lalu (1903) telah mencatat bahwa hubungan dan komunikasi di dalam masyarakat lebih erat antara orangorang yang serupa dalam pendidikan, tingkat ekonomi serta pekerjaannya, bergantung pada kesamaan dan perbedaan yang menjadi tolok ukur atau isu saat berlangsungnya homofili.

Pada satu sisi, homofili menggiring perubahan pada kalangan menengah ke atas Masyarakat Dusun Punik ke arah yang semakin kompetitif dengan sesamanya sehingga cenderung over-adopsi, meninggalkan kelas di bawahnya sehingga semakin mempertajam konflik dan sentimen terkait keinovasian. Pola interaksi yang disebabkan oleh homofili membawa dampak perubahan pada pola interaksi yang horziontal dan bukan vertikal. Dengan demikian, interaksi antarwarga Punik tidak lagi benar-benar didasarkan atas isu ladang kopi, isu anak, atau stok kebutuhan pokok mereka selama setahun yang cenderung lebih egaliter, melainkan lebih atas dasar kemampuan berinovasi yang cenderung berkelas. Sebagaimana dikatakan Ogburn bahwa masalah sosial tercipta karena kekurangan akan penyesuaian (Bachtiar, 2006). Masalah-masalah yang muncul sebagai dampak perubahan yang disebabkan oleh PLTD dalam konteks pernyataan di atas sejatinya merupakan keniscayaan dalam proses adaptasi struktur menuju keseimbangan kembali (equilibrium). Keterlambatan penyesuaian yang dilakukan oleh berbagai segmen dalam sistem sosial masyarakat Punik sehingga memicu konflik dan sentimen kepemilikan dalam pandangan Ogburn merupakan kelaziman, sebab menurutnya kebudayaan immaterial seringkali lebih lambat dalam mengikuti perubahan budaya material. Inovasi PLTD di tengah-tengah Masyarakat Dusun Punik sekarang ini belumlah sampai pada tahapan difusi yang sempurna untuk sampai ke tahap keseimbangan kembali (equilibrium). Beberapa pihak dan komponen budaya lainnya masih belum terhubung dengan manifestasi fungsi PLTD walaupun dengan berbagai alasan yang berbeda, mulai dari alasan ideologi, sampai pada alasan ekonomi dan teknis. Menurut Ogburn, suatu inovasi (dalam kasus ini PLTD) untuk sampai pada perubahan sosial yang sempurna harus menempuh empat tahap yaitu penemuan, akumulasi, difusi dan penyesuaian. Artinya, walaupun PLTD telah terdifusi pada mayoritas Masyarakat Dusun Punik, tetapi selama unsur-unsur budaya lainnya tidak tersesuaikan, maka perubahan sosial yang dihasilkan belumlah sampai pada perubahan yang sempurna atau dalam istilah fungsional struktural mencapai equilibrium (keseimbangan).

Memasuki fase kedua difusi inovasi, yaitu di tahun kedua masuknya PLTD di Masyarakat 
Dusun Punik, implementasi fungsi PLTD telah menyentuh dan mewarnai tradisi yang terkait dengan hiburan dan kesenian masyarakat setempat. Lazimnya masyarakat pedesaan yang tradisional, kesenian yang dijadikan suguhan hiburan dan dipentaskan pada event dan acara-cara tertentu, seperti pasca panen, peringatan hari besar, ataupun di pesta-pesta pernikahan senantiasa mengacu pada tradisi mata pencaharian, nilai kepercayaan, serta norma-norma setempat. Sebagai contoh, sebelum era pra-PLTD, pascapanen padi maupun panen kopi, masyarakat setempat biasanya secara rutin mengadakan pentas keterampilan ketangkasan yang disebut "berempuk", yaitu pentas adu ketangkasan antara dua orang pria layaknya tinju dengan kepalan tangan yang dibalut pelepah padi. Contoh lainnya yaitu di masa musim hujan, olah raga keterampilan yang menjadi suguhan pentas budaya yang secara rutin diadakan di hari-hari besar biasanya berupa "karapan kerbau", dan di acara-acara penikahan dipentaskan kesenian bemuatan nilai agama yang dikompilasi dengan tradisi yaitu "ratib".

Pascakehadiran PLTD, berbagai pentas kesenian dan budaya tersebut di atas sudah mulai ditinggalkan ataupun dimodifikasi corak dan muatan nilainya. Di hari 17 Agustus yang tetap rutin dirayakan setiap tahunnya, pentas budaya tidak lagi memanfaatkan lahan pertanian sebagai lokasi dan kerbau sebagai alat atraksi (karapan kerbau), fungsi lokasi yaitu lahan pertanian sebagai simbol mata pencaharian digantikan dengan lapangan umum dan panggung, sedangkan kerbau sebagai simbol budaya kerja digantikan dengan diesel, panggung, elektone (sejenis music keyboard), serta sound system atau speaker (lomba karaoke).

Perubahan-perubahan yang terjadi pada aspek kultur atau tradisi di atas bukan tanpa potensi konflik. Beberapa orang yang sebelumnya memiliki kapasitas dan otoritas terkait tradisi tersebut menarik diri dari kegiatan-kegiatan yang bernuansi inovasi tersebut, dan memilih peran oposisi sebagaimana para pemukanya yaitu tokoh agama dan tokoh adat setempat. Menjadi sub-ordinat setelah sekian lama sebagai super-ordinat (walaupun dalam konteks yang berbeda) tentu merupakan alasan bagi mencuatnya konflik struktural. Walaupun dalam makna-makna tertentu konflik dapat bersifat fungsional sebagaimana yang dikatakan Lewis Coser (Ritzer dan Goodman. 2003), namun di dalam konteks difusi inovasi PLTD konflik semacam ini tidak produktif terhadap dampak yang diharapkan oleh inovator. Konflik dalam konteks ini hanya fungsional terhadap homofilitas persepsi dan sikap adopsi yang antagonistik atau saling bertentangan di dalam masyarakat Punik.

Fungsionalnya konflik keinovasian PLTD terhadap homofilitas yang dimaksud di atas terbatas pada aspek-aspek berikut ini (Coser): Pertama, semakin meningkatnya ikatan internal kelompok yang kecewa atau bahkan menolak PLTD, yang mana sebagian di antaranya datang dari kalangan ekonomi lemah, sebagian lagi yang memendam kekecewaan terhadap regulasi tagihan PLTD serta sisanya adalah yang menyimpan sentimen terhadap perbedaan tingkat keinovasian pada faktor kepemilikan fasilitas. Kedua, Beberapa orang yang sebelum kemunculan konflik seputar inovasi PLTD relatif dinilai deviant dan terisolasi, tetapi dengan isu konflik tersebut menjadi ikon inovasi bagi kalangan yang proPLTD.

Fakta di atas juga menggambarkan bahwa kehadiran PLTD telah menimbulkan difersifikasi otoritas dan kekuasaan pada masyarakat Punik, sebagaimana dikatakan Dahrendrof bahwa otoritas tidak bersifat konstan karena melekat pada posisi dan bukan pada individu (Kanto, 2011). Dengan demikian, individu yang sebelumnya menyandang otoritas dan ketokohan karena kapasitas dan kapabiltas budaya serta tradisi Punik yang dimilikinya akan tertanggal di hadapan teknologi dan inovasi. Sebaliknya, mereka yang memiliki kapabilitas dan kapasitas terkait PLTD, dengan sendirinya akan memegang otoritas dan ketokohan dalam konteks tersebut.

Meluasnya praktik tradisi yang dinilai menyimpang dari norma sebelumnya sebagai konsekuensi yang tidak terhindarkan 
dari manifestasi PLTD, berimplikasi pada morphogenesis-normatif. Betapa tidak, dari keseluruhan jumlah masyarwakat di Punik yang berjumlah $180 \mathrm{KK}$, hanya terdapat 57 KK yang memiliki televisi, walaupun yang mengadopsi PLTD mencapai 129 KK. Berarti dapat dipastikan,bahwa setiap KK yang memiliki televisi yang berjumlah 57 KK tersebut menyerap hampir semua warga Punik di dalam praktik "nonton bersama", kecuali mereka yang benar-benar resisten secara ideologis dengan PLTD dan menolak semua bentuk implementasinya. Konsekuensi normatif dari kenyataan tersebut berimplikasi pada perilaku "nonton bareng" yang dampakdampak normatifnya: (a) duduk-duduk di pinggir jalan yang melanggar tabu, (b) bertamu sampai larut malam yang melanggar tabu pula, (c) menimbulkan kegaduhan yang melanggar norma adat-istiadat, (d) tidak jelasnya batasbatas privasi yang melanggar nilai serta berbagai implikasi normatif lainnya.

Morphogenesis-normatif yang terjadi sebagai konsekuensi massifnya praktik deviatif di atas berlangsung melalui mekanisme internal yaitu penyingkiran norma yang ada, walaupun mayoritas pelakunya (deviant) merupakan penyimpang kategori dalam batas kelayakan, hanya sebagian kecil yang dalam kategori penyimpang nonkompromi (Sztompka, 1993). Ketika diwawancara, banyak informan pelaku nonton bareng yang duduk di pinggir-pinggi jalan tidak menyangkal bahwa apa yang mereka lakukan memang melanggar tabu, dan merekapun mengakui bahwa demi kebaikan hidup bersama, norma tersebut menjadi sah. Hanya saja mereka merasa bahwa norma tersebut terlalu menuntut di tengah keniscayaan karena situasi yang tidak dapat mereka dihindari. Tidak salah lagi bahwa fenomena di atas merupakan bagian dari morphogenesis-normatif sebagaimana dikatakan Jacobsen berikut ini: "Penyingkiran norma (Morphogenesis-Normatif) adalah sejenis pelanggaran sub-tipe norma tertentu baik dengan sengaja maupun dengan tipu daya (Sztompka, 1993)".

\section{SIMPULAN}

Berawal dari fokus penelitian, kemudian dilanjutkan dengan kajian dan pembahasan, analisis, dan diskripsi di atas, maka dapat ditarik beberapa simpulan sebagai berikut: perubahan sosial yang terjadi pada masyarakat desa terpencil Punik sebagai dampak dari implementasi listrik tenaga diesel (PLTD) yaitu mesin genset mencakup perubahan-perubahan (1) Pergeseran basis pelapisan atau ukuran status sosial (stratifikasi sosial). (2) Faktor kepemilikan rumpun teknologi inovasi serta berbagai bentuk manifestasinya turut serta menjadi faktor penentu naik-turunnya status sosial. Sejauhmana keragaman teknologi yang dimiliki, sejauhmana tingkat kecanggihannya, seberapa banyak orang yang mampu memiliki, dan seberapa mahal harganya turut menentukan penghargaan dan prestise yang disandang oleh pemiliknya.

Perubahan berikutnya yaitu perubahan distribusi peran dalam keluarga dan masyarakat. Distribusi peran yang sebelumnya statis serta mengacu pada norma dan tabu (primordial) berubah ke arah distribusi peran yang berbasis pada azas produktivitas, pragmatisitas, dan ketersediaan sumber daya yang memadai, di mana distribusi peran tidak lagi terlalu rigid mengacu pada alokasi jenis kelamin dan usia.

Perubahan sosial berikutnya yaitu perubahan seputar pergeseran basis dan orientasi interaksi dan kerjasama, dari unsur efektivitas dan orientasi keintiman, menguatkan hubungan kekerabatan serta altruisme bergeser menjadi affective neutrality, individual, dan berorientasi ekonomi. Selanjutnya yaitu perubahan seputar pergeseran tradisi, berbagai bentuk tradisi oralistik-tradisional dan tradisi yang bermuatan kebersamaan serta pengukuhan hubungan antara individu direduksi atau bahkan digeser oleh fungsi-fungsi rumpun teknologi inovasi. Tradisi-tradisi bernuansa kolektivitas lebih dapat terselenggara melalui stimulus teknologi media hiburan.

Perubahan sosial yang sangat mencolok berikutnya yaitu perubahan adat dan budaya. Adat dan budaya yang sebelumnya bertumpu 
pada sistem mata pencaharian, pada aktualisasi peran manusia dan peralatan tradisional, tergeser atau tereduksi oleh budaya yang bertumpu pada implementasi dan manifestasi teknologi berbasis fungsi listrik. Momentummomentum sosial beradaptasi berdasarkan keteralokasian sumber daya kelistrikan. Alokasi waktu mengalami persesuaian dengan keteralokasian fungsi listrik dan mengabaikan keteralokasian sumber daya manusia yang kemudian berdampak pada berkurangnya alokasi kebersamaan dan produktivitas kerja serta bertambahnya waktu luang dan hiburan.

\section{UCAPAN TERIMAKASIH}

Atas selesainya penyusunan naskah ini tidak lupa penulis sampaikan rasa terima kasih kepada segenap pihak, Warga Dusun Punik, Kepala Desa Batu Dulang, Kecamatan Lanteh, Kabupaten Sumbawa, segenap warga yang terlibat sebagai informan atau yang membantu kegiatan peneliti, segenap sejawat dan kawan di Program Studi Sosiologi serta seluruh anggota keluarga yang selalu memotivasi.

\section{DAFTAR PUSTAKA}

Abraham. Francis. M. 1982. Modern Sociological Theory: An Introduction. Oxford Univesity Press. Delhi.

Arifin. 2003. Fenomena Sosial dalam Perspektif Fungsional Struktural, Konflik dan Interaksionisme Simbolik (Sebuah Pemahaman Awal). IKIP Budi Utomo. Malang.

Arikunto. Suharsini. 1992. Prosedur Penelitian. Rineka Cipta. Jakarta.

Bachtiar. Wardi. 2006. Sosiologi Klasik: Dari Comte Hingga Parson. Rosdakarya. Bandung.

Blummer. Herbert. 1969. Symbolik Interaksionism: Perspekticer and Method. Eagle Wood Cliffs. N). Prentice-Hall. inc.

Brannen. Yulia. 1993. Mixing Method Qualitative and Quantitative Research. Evabury Aldershot. Brookfield Lisa. Hongkong, Singapura, Sydney.
Bappedda Kab.Sumbawa. 2005. Kabupaten Sumbawa: Geografis. Topografis. Demografis. Sumbawa Besar.

Brown A. 1981. Innovation Diffusion: A New Perpective. Westview Press. Boulder.

Bogdan. Robert. K. 1982. Design Issues in Qualitative Research: The Case of Knowledge Utilization Studies. Abt Associates. Washington D.C.

Bogdan. Robert. 1975. Introduction to Qualitative Research Methods: A Phenomenological Approch to The Social Science. Wiley. New York.

Cambell. Tom. 1994. Seven Theories of Human Society. Budi Hardiman. Kanisius (Penerjemah). Yogyakarta.

Craib. Ian. 1992. Modern Social Theory: From Parsons to Habermas. T. Effendi. (Penerjemah) CV. Rajawali. Jakarta.

Etzioni. Eva and Amiatai Etzioni (1967). Social Change: Sources. Pattern and Consequences. Basic Books. Inc. Publishers. New York.

Etzioni. A. dan Halevy. Eva. Etzioni (eds). 1973. Social Changes: Source, Patterns and Consequences. Basic Books. New York.

Faisal. Singgih. 1990. Penelitian Kualitatif. YA3. Malang.

Featherstone. Mike. 1993. Consumer Conture dan Postmodernism. Sage Publications. London.

Giddens. Anthony. 2001. The Global Third Way Debate. Polity Press. Cambridge. 2003. The Constitution of Society, Teori Strukturasi untuk Analisis Sosial. Adi Loka Sujono (penerjemah). Pedati. Pasuruan.

Goodman. Douglas J. 2004. Teori Sosiologi Modern. Prenada Media. Jakarta.

Hanafi. Hasan. 2007. Aktualisasi Humanisme Islam di Tengah Krisis Humanisme. Pustaka Pelajar. Yogyakarta.

Hanafi. Abdillah. 1987. Memasyarakatkan IdeIde Baru. Usaha Nasional. Surabaya. 
Hard Bendix. Rein.. Martin Lipset. Seymour. 1989. Class, Status and Power: Social Stratification in Comparative Perspective. The free Press. New York.

Ibrahim. M. 1988. Proses adopsi dan pola difusi. PT.Rajagrafindo Persada. Jakarta.

Johnson. D. Paul.1994. Teori Sosiologi Klasikdan Modern 1 dan 2. Robert M.Z.Lawang (Penerjemah). Gramedia Pustaka Islam. Jakarta.

Jhonson. Doyle. Paul. Teori Sosiologi I. Terjemahan Robert M.Z. Lawang. PT. Gramedia. 1986. Jakarta.

Kanto. Sanggar. 2011. Perspektif Modernisasi dan Perubahan Sosial: Suatu Tinjauan Teoritik dan Empirik. Universitas Brawijaya Press (UB Press). Malang.

Khairuddin. 2008. Sosiologi Keluarga. Liberty. Yogyakarta.

Kotler. Philip., Zaltman. Gerald., Kauman. Ira. 1972. Creating Social Change. Holt. Rinehart and Winston. New York.

Katz, Elihu. 1961. "The Social Itinerary of Social Change: Two Studies on the Diffusion of Innovation." In Wilbur Schramm, ed. Stand for California. Stanford University, Institute for Communication Reseach.

Kolter. Philip. 1972. Creating Social Change. Hold Rinehart and Winston Inc. New York.

Kasnawi. 2000. Perubahan Sosial dan Pembangunan. Ghalia Indonesia. Jakarta.

Lauer. Robert. H. 1993. Perspective on Social Change. Alimandan (Penerjemah). PT. Rineka Cipta. Jakarta.

Linton, Ralph. 1963. Psychological Frontiers of Society. Columbia University Press. Columbia.

Lauer, Robert. H. 1993. Perspektif tentang Perubahan Sosial. PT. Rhineka Cipta. Jakarta.

Muslimin. 2002. Metodologi Penelitian Bidang Sosial. UMM Press. Malang.
Malihah. Elly. 2010. Dinamika Sosial, Pokok Materi Sosiologi. FPIPS UNILA.

Manners Robert A. dan Kaplan. David. Culture Theory. Englewood Cliffs, N.J. Prentice-Hall

Murtadha. Mutahhari. 1985. Society and History. M. Hasen (Penerjemah). Mizan. Jakarta.

Miles. Metthew B and Huberman A. Michael. 1992. Qualitatif Data Analysis. Sage Publication Inc.

Merton. Robert.K. 1962. Social Theory and Social Structure. The Free Press. New York.

Mayer. Robert. R. dan E.G.Wood. 1984. Rancangan Penelitian Sosial. Ihsan Suhadi (Penerjemah). CV. Rajawali. Jakarta.

Moleong. J.L. 2008. Metodologi Penelitian Kualitatif. PT. Remaja Rosdakarta. Bandung.

Mundi. Paul. 2000. Adopsi dan Adaptasi Teknologi Baru. PAAPT3. Bogor

Mulyana. D. dan Solatun, (ed.), 2007. Metode Penelitian Komunikasi; Contoh-contoh Penelitian Kualitatif dengan Pendekatan Praktis. Remaja Rosdakarya. Bandung.

Mulyana D. 2001. Metodologi Penelitian Kualitatif; Paradigma Baru Ilmu Komunikasi dan Ilmu Sosial Lainnya. Remaja Rosdakarya. Bandung. 2003. Komunikasi Efektif: Suatu Pendekatan Lintas Budaya. Remaja Rosdakarya. Bandung.

Maran. Raga. Rafael. 2000. Manusia dan Kebudayaan:Dalam PerspektifImu Budaya Dasar. Rineka Cipta. Bandung.

Mar'at. 1982. Sikap Manusia, Perubahan, serta Pengukurannya. Ghalia Indonesia. Jakarta.

Moore. David. 1992. From Psychobiollogical Description to Sociological Exlpanation: Ethnograpic comments on The Concept of. 
Moore. Robert W. (1968). Indicator of Sosial Change. USA.

Nazir. 2003. Metode Penelitian. Ghalia Indonesia. 2003. Jakarta.

N.J.. Smeller. Social Change In The Industrial Revolution. University of Chicago Press. 1966. Chicago.

Ogburn. Fielding. 1964. Social Change With Respect to Culture and Original Nature. Mass. Smith. Glouceser.

O. Ottif. Mustafa. Holzner. Burkart. Suda. Zdenek. Sosiologi Modernisasi: Telaah Kritis tentang Teori Riset dan Realitas. Tiara Wacana. 1989. Yogyakarta.

Pool. Robert. 1997. Beyond Engineering: How Society Shapes Technology. Oxford University Press. New York.

Payne. M. 1997. Social Work and Community Care. McMillan. London.

Priyono. O.S. dan A.M.W. Pranarka. 1996. Pemberdayaan: Konsep, Kebijakan dan Implementasi. Center for Strategic and International Studies (CSIS). Jakarta.

Pranaka dan Vidhyandika. 1996. Pemberdayaan (Empowerment). Centre of Strategic and International Studies (CSIS). Jakarta.

Poloma. Margaret. 2000. Teori Sosiologi Kontemporer. Yasogama (Penerjemah). PT. Raja Grafindo. Jakarta.

Parker.Des.1981. Basic Grapchic Communication. Macmillan. South Melbourne.

Parker. Lee. 1974. A Personal Perspective. ERIC Clearinghouse. Washingtong D.C.

Rogers. E.M 1983. Diffusion of innovations. 3rd ed. Free Press, New York.

1995. Diffusions of Innovations, Forth Edition. Free Press. New York.

1969. Diffusion of Innovations: Educational Change in Thai Government Secondary Schools. ERIC Clearinghose. Wasington D.C.

Rogers. E.M. and F.Shoemaker. 1971. Communication of Innovation: A Cross-
Cultural Approach. The Free Press. New York.

1971. Communication of Innovations. The Free Press. London.

Ritzer George dan Goodman.Douglas.J. 2011. Teori Sosiologi Modern (Terjemahan Alimandan). Kencana Prenada Media Group. Jakarta.

Ritzer. George. 1982. Socilogy Experiencing a Changing Society. Allyn and Bacon. Inc. Bonston.

2002. Sosiologi Ilmu Pengetahuan Berparadigma Ganda. Alimandan (Penerjemah). Grafindo Persada. Jakarta.

Rosenau . 1997. Memahami Perliku Orang Lain. Bina Cipta. Jakarta.

Rubin. Herbert. 1992. Community Organizing and Development. Mac Millen Publishing Company. New York.

Rogers, E. M., dan Kincaid, D. L. (1981). Communication networks: Toward a new paradigm for research (p. 386). Free Press.

Ritzer. George. 1982. Socilogy Experiencing a Changing Society. Allyn and Bacon. Inc. Bonston. 2004. Teori Sosiologi. Cetakan Kelima. Kreasi Wacana Offset. Bantul.

S. Susanto. Astrid. Phil. 1984. Sosiologi Pembangunan. Binacipta. Jakarta.

Singarimbun. Masri. Effendi. Sofyan. 1989. Metode Penelitian Survei. LP3ES Jakarta.

Santoso. Ahmad. 2000. Kiat Memahami Teoriteori Hermenetika. Pustaka Pelajar. Jakarta.

Soekanto. Soerjono (1984). Teori Sosiologi tentang Perubahan Sosial. PT.Ghalia Indonesia. Jakarta.

2000. Sosilogi: Suatu Pengantar. PT. Raja Grafindo Persada. Jakarta. 
1983. Teori Sosiologi tentang Perubahan Sosial. PT.Ghalia Indonesia. Jakarta.

(ed). 1993. Menusia dan Kebudayaan di Indonesia. Djambatan. Jakarta.

2002.. Kebudayaan. Mentalitet dan Pembangunan..Gramedia. Jakarta Sosilogi: Suatu Pengantar. PT. Raja Grafindo Persada. 2002. Jakarta.

Syaodih.Sukmadinata. 2006. Metode Penelitian Pendidikan. Remaja Rosdakarya. Bandung.

Simandjuntak. B. 1980. Perubahan Sosio Kultural. Tarsito. Bandung.

Soehartono. Irawan. 1999. Metode Penelitian Sosial. Rineka Cipta. Bandung.

Soemardjan. Selo. 1997. Kemiskinan: Suatu Pandangan Sosiologi. Jurnal Sosiologi Indonesia. ISI Phubliser. Jakarta.

Soekarwi. 1988. Prinsip Dasar: Komunikasi Pertanian. UI. Press. Jakarta.
Suradi. 2003. Kehidupan Masyarakat Desa. Studi Sosial Budaya Komunitas Osing di Banyuwangi. Puslitbang UKS.

Surakhmad. Winarno. 1982. Pengantar Penelitian Ilmiah, Dasar, Metode, Teknik. Transito. Bandung.

Simandjuntak. B. 1980. Perubahan Sosio Kultural. Tarsito. Bandung.

Siporin. Max. 1975. Introduction to Sosial Work Practice. Mac Millan Phubliser Co. Inc. New York.

Soehartono. Irawan. 1999. Metode Penelitian Sosial. Rineka Cipta. Bandung.

Soemardjan. Selo. 1997. Kemiskinan: Suatu Pandangan Sosiologi. Jurnal Sosiologi Indonesia. ISI. Phubliser. Jakarta.

Sztompka. Piotr. 1993. Sosiologi Perubahan Sosial (Terjemahan Alimandan). Prenada. Jakarta.

Swasono. Mutia Farida. 2002. Prospek dan Permasalahan perlindungan dalam Pemberdayaan Masyarakat Desa. Direktorat KAT. Jakarta.

Saeed. Khaled and Dennis L. Meadows. 1994. Development Planning and Policy Design: A System Dinamics Approach. Athenaeum Press. New Castle.

Suwarsono dan Alvin Y. S. 1994. Perubahan Sosial dan Pembangunan. LP3ES. Jakarta. 